\title{
An unusual Wilms tumor with urethral recurrence: rare case report and literature review
}

\author{
Elizaveta Chernetsova ${ }^{1}$, Ahmed Nasr ${ }^{2}$, Luis Guerra ${ }^{3}$, Bilaal Kabir ${ }^{1}$, Marie J eongMin Kim ${ }^{1}$, J oseph \\ de Nanassy ${ }^{1}$, Katrina J Sullivan ${ }^{2}$, Dina El Demellawy ${ }^{1}$ \\ 1. Department of Pathology and Laboratory Medicine, Children's Hospital of Eastern Ontario, University of Ottawa, Ottawa, \\ Ontario, Canada. 2. Department of Pediatric Surgery, Children's Hospital of Eastern Ontario, University of Ottawa, Ottawa, \\ Ontario, Canada. 3. Department of Pediatric Urology, Children's Hospital of Eastern Ontario, University of Ottawa, Ottawa, \\ Ontario, Canada.
}

Correspondence: Dina El Demellawy, MD PhD FRCPC. Associate Professor - University of Ottawa. Pediatric Pathologist Children's Hospital of Eastern Ontario. Address: 401 Smyth Road Ottawa, ON K1H 8L1, Ottawa, Ontario, Canada. E-mail: deldemellawy@cheo.on.ca

Received: August 16, 2015

Accepted: August 30, 2015

Online Published: September 8, 2015

DOI : $10.5430 /$ crcp.v2n4p65

URL: http://dx.doi.org/10.5430/crcp.v2n4p65

\begin{abstract}
s
Wilms tumor (WT) is the most common malignant, solid renal tumor in children. Most recurrent or metastatic WT occur within the first 2 years after the primary diagnosis. Urethral metastases in WT are very unusual and to the best of our knowledge have been reported only twice within the English literature. Those two cases had a poor outcome suggesting that urethral metastasis in recurrent WT is an indicator of poor prognosis. We report a third case of urethral recurrence of WT and reviewed the two previously reported cases in details.
\end{abstract}

\section{Key words}

Wilms tumor, Pediatric renal tumors, Urethral neoplasms, Recurrent Wilms, Kidney tumors in children, Metastatic Wilms, Urethral metastasis

\section{I ntroduction}

Urothelial extension of WT is rare, with only 16 previous cases of ureteral metastases or extension into the non-renal urothelial passages reported ${ }^{[1-15]}$.

The majority of these cases represent urothelial extension and not true metastases. Metastases of WT is exceeding rare, with only two existing cases identified through a review of the literature. Here we report an unusual case of urethral recurrence 10 months after initial radical therapy for WT.

\section{Case reports}

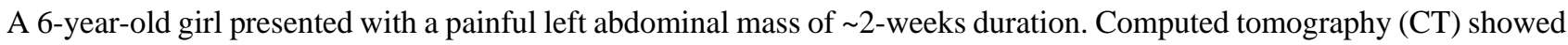
a $13.0 \mathrm{~cm} \times 10.0 \mathrm{~cm} \times 8.8 \mathrm{~cm}$ left renal mass and a $0.7 \mathrm{~cm} \times 0.8 \mathrm{~cm} \times 2.3 \mathrm{~cm}$ para-aortic lymph node. There was no 
extension through the left renal vein or inferior vena cava (IVC); however, bilateral innumerable pulmonary nodules were identified. The largest nodule measured $1.2 \mathrm{~cm} \times 2.2 \mathrm{~cm}$. Additionally the patient had mild ptosis of the right eyelid, mild midfacial hypoplasia, facial asymmetry, finger syndactyly, cutaneous infantile hemangioma, and hemi-hypertrophy of the left extremities. Beckwith-Wiedemann syndrome testing was negative as noted by normal 11p15.5 gene and methylation of H19DMR, and the absence of paternal UPD11 and mutations in CDKN1C and DICER1 gene sequencing. A single nucleotide polymorphism (SNP) array performed on the tumor showed no mosaicism for paternal UPD11p15. A comparative genomic hybridization (CGH) array performed on the patient's blood was normal and WAGR deletion was not detected.

As for the patient's past medical history, the patient's mother is a G7, T4, P0, A3, L4. Pregnancy history was uncomplicated with delivery at 39 weeks of gestation and a birth weight was 3,600 grams, but the placenta revealed a 2-vessel umbilical cord. Prior to her current presentation she complained of lower extremity purpura and arthralgia, and was diagnosed with Henoch Schonlein purpura. She was followed with urinary dipsticks and her symptoms resolved.

Her family history was significant for pancreatic cancer in her grandfather and pancreaticobiliary cancer in her grandmother whose sister and brother both died from cancers of unknown origin.

Based on imaging studies the tumor was diagnosed as WT; the patient had a left nephrectomy with simultaneous placement of a Port-A-Catheter for chemotherapy.

\subsection{Pathological findings}

The radical nephrectomy was entirely encapsulated and weighed 938 grams. Cut surface showed a $14.2 \mathrm{~cm} \times 12.4 \mathrm{~cm} \times$ $9 \mathrm{~cm}$ well-demarcated grey beige tumor replacing $~ 90 \%$ of the pre-existing renal parenchyma. Para-aortic and portal lymph nodes measuring $1 \mathrm{~cm}$ and $2.5 \mathrm{~cm}$ were received.

Microscopically the findings were of triphasic WT, blastema predominant, favorable histology with a brisk mitotic activity, extensive vascular and lymphatic invasion, tumor extension into the renal sinus and metastasis in the para-aortic lymph node. The renal capsule and the ureteric and vascular margins were clear. Nephrogenic rests were not identified. Extension into the ureteric pelvis urothelium was not noted.

\subsection{Clinical follow up}

The patient underwent radiotherapy and three rounds of chemotherapy with ICE protocol (Carboplatin, Etoposide, Ifosfamide, Mesna). Follow-up imaging 4 months after surgery revealed no signs of tumor. However, 6 months later the patient presented to the Emergency Room with urinary retention. Magnetic resonance imaging (MRI) showed a $3.3 \mathrm{~cm} \times$ $3.6 \mathrm{~cm} \times 5.1 \mathrm{~cm}$ pelvic retropubic mass surrounding the urethra and anterior to the vagina but sparing the urinary bladder (sees Figure 1). A second $2.3 \mathrm{~cm} \times 1.2 \mathrm{~cm} \times 2 \mathrm{~cm}$ mass on the lateral wall of the right ischio-rectal fossa was also identified. These secondary unrelated malignancies were worrisome, particularly the rhabdomyosarcoma (sarcoma botryoides) tumor, due to their unusual nature.

Laparotomy with periurethral mass biopsy revealed bundles of urethral smooth muscle infiltrated by scattered islands of hyperchromatic small round blue cells (see Figure 2). These cells showed a high nuclear-to-cytoplasmic ratio and a mildly elongated contour, with morphological features similar to the patient's original tumour. Anaplasia or evidence of differentiation was not identified. Using immunohistochemistry the tumor cells were found to express WT-1 and CD56, but were negative for all muscle markers tested (myo D1, myogenin, and myoglobin) in keeping with metastatic/recurrent WT. The urethral urothelium was free of tumor.

The patient was treated by ICE regimen (Carboplatin, Etoposide, Ifosfamide, Mesna) followed by cycle 5 as per protocol AEWS1031 (vincristine, cyclophosphamide, topotecan). At 22 months follow up, she showed no evidence of disease. 

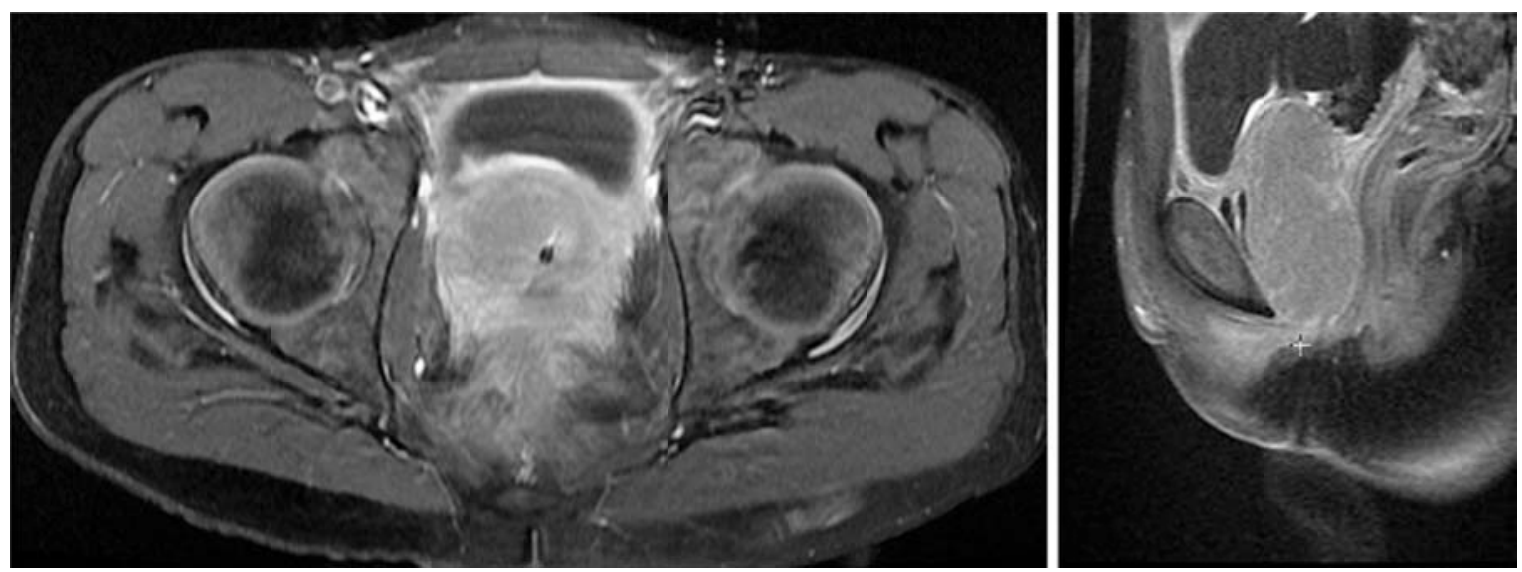

Figure 1. MRI showing recurrent Wilms tumor in the urethra. This imaging is very unusual for Wilm's tumor and consideration of rhabdomyosarcoma particularly sarcoma botryoides is considered.

Figure 2. Recurrent Wilms tumor infiltrating the urethral wall smooth muscle, sparing the urothelium (arrow highlighting urethral mucosal epithelium) $(\mathrm{HE} \times 200)$. Inset highlighting WT-1 diffuse and string nuclear expression of the Wilms tumor cells (WT-1 $\times 400)$.

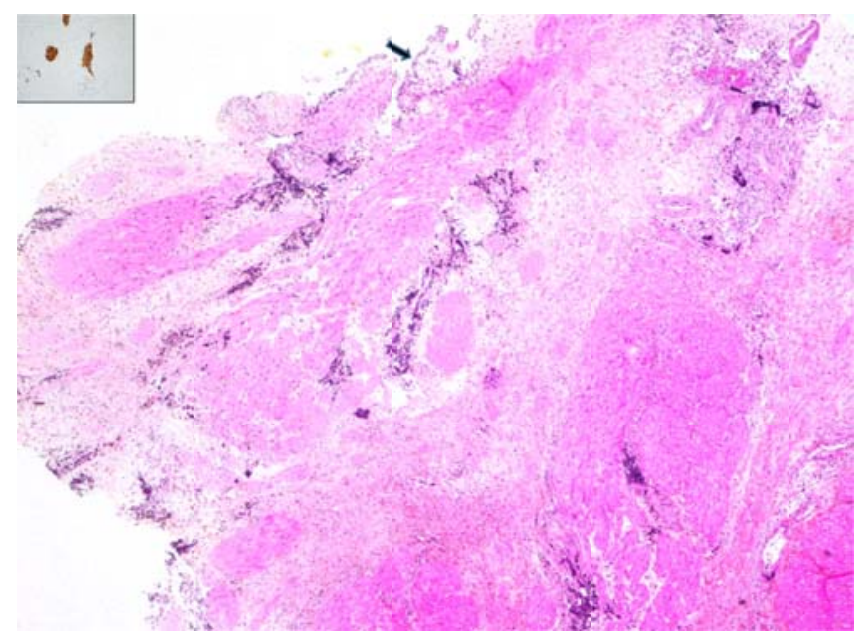

\section{Discussions}

WT is the second most common solid visceral cancer of childhood and the fifth most common pediatric malignancy overall. It represents approximately $6 \%$ of all pediatric cancers and accounts for more than $95 \%$ of all tumors of the kidney in the pediatric age group ${ }^{[17,18]}$. In the United States, about 500 children are diagnosed with WT each year ${ }^{[19]}$. Approximately $75 \%$ of the cases occur in children less than 5 years of age with a peak incidence at 2 to 3 years of age ${ }^{\text {[20] }}$.

It is extremely unusual for WT to present as a metastatic abdominal mass in a child who otherwise appears healthy, as noted in our case. Several associated congenital anomalies, including aniridia, hemihypertrophy, cryptorchidism, and hypospadias, have been reported with WT, however our patient did not have any genitourinary anomalies. She did have hemihypertrophy associated with a strong family history of malignant tumors which raised concerns of Beckwith-Wiedemann syndrome predisposing to the development of WT. This possibility was ruled out by genetic testing (11p15.5 gene was negative; and negative paternal UPD11).

Despite the significant clinical history of prior presentation for Henoch-Schonlein purpura noted in our patient, there was no clinical evidence of an underlying chronic renal disease. Neither were any features that would suggest the possibilities of Denys-Drash or Frasier syndrome noted, and no WT1 gene mutation was identified. Germline mutations in DICER1, a gene encoding an endoribonuclease critical for the generation of miRNAs which indicates a predisposition to malignant tumors ${ }^{[21]}$ including WT, were not detected. Thus, our case is best classified a sporadic WT i.e., WT with no evidence of 
an underlying syndrome, despite the presence of hemihypertrophy. This is not unusual, as the majority of WT cases are classified as sporadic ${ }^{[22]}$, with germline mutation thought to only account for about $10 \%-15 \%$ of WT ${ }^{[21]}$.

Recurrence of WT as a metastatic tumor is exceeding rare. Risk of recurrence depends on a variety of factors including tumor stage, histology, patient age, tumor weight, microscopic residual at resection margins, lymph node involvement, spillage of tumor during surgery, overall peritoneal soilage, invasion into adjacent organs, surgeon's assessment of whether complete removal of the tumor had been achieved or not ${ }^{[23]}$, lung nodule response, and loss of heterozygosity $(\mathrm{LOH})$ at chromosomes $1 \mathrm{p}$ and $16 \mathrm{q}$ as prognostic factors for recurrence of $\mathrm{WT}{ }^{[24]}$. $\mathrm{LOH}$ at chromosomes $1 \mathrm{p}$ and $16 \mathrm{q}$ is associated with greater risks of relapse and mortality ${ }^{[25,26]}$. Approximate relapse rates are believed to vary between $4.3 \%$ and $22.4 \%$ for favorable histology and $42 \%$ to $60 \%$ for unfavorable histology, respectively ${ }^{[27,28]}$. Most recurrent WT have been reported to occur in the first 2 years after the primary diagnosis, however late relapse of WT can also occur with one documented case of relapse occurring 25 years after initial treatment ${ }^{[29]}$.

Table 1. Wilms tumor reported cases with urethral metastasis/recurrence

\begin{tabular}{|c|c|c|c|c|c|c|c|}
\hline Cases & Age/Gender/Laterality & $\mathrm{C} / \mathrm{O}$ & Management & $\begin{array}{l}\text { Tumor } \\
\text { Rupture }\end{array}$ & Pathology & Relapse & Outcome \\
\hline $\begin{array}{l}\text { Woodhead } \\
\text { et al. }{ }^{[1]}\end{array}$ & 18 (m)/Boy/Right & Hem. & $\mathrm{N}+\mathrm{C}+\mathrm{R}$ & N/A & N/A & 6 (m) Hem. & $\begin{array}{l}\text { Death } \\
\text { (lung mets) }\end{array}$ \\
\hline $\begin{array}{l}\text { Lowe } \\
\text { et al. }{ }^{[2]}\end{array}$ & 3 (m)/Boy/Bilateral & Hem. & Bilateral N + C & N/A & $\begin{array}{l}\text { Initially, FH } \\
\text { Relapse, UFH }\end{array}$ & $\begin{array}{l}78(\mathrm{~m}) \text { Hem. } \\
\text { lung mets }\end{array}$ & $\begin{array}{l}\text { Palliative } \\
\text { care }\end{array}$ \\
\hline $\begin{array}{l}\text { Chernetsova } \\
\text { et al. }\end{array}$ & $\begin{array}{l}72 \text { (m)/Girl/Left LN, } \\
\text { lung mets }\end{array}$ & Mass & Mass $\mathrm{N}^{*}+\mathrm{C}+\mathrm{R}$ & No & $\begin{array}{l}\text { FH in initial \& } \\
\text { relapse }\end{array}$ & $\begin{array}{l}10(\mathrm{~m}) \\
\text { Anuria }\end{array}$ & $\begin{array}{l}\mathrm{C}+\mathrm{R} \text { In } \\
\text { remission }\end{array}$ \\
\hline
\end{tabular}

Note. $\mathrm{C} / \mathrm{O}=$ complaint, $\sim$ Relapse $=$ Relapse duration \& presentation, $(\mathrm{m})=$ months, $\mathrm{LN}=$ lymph node, Mets = metastasis, $\mathrm{N}=\mathrm{Nephrectomy,} \mathrm{N}^{*}=$ Nephrectomy and partial ureteroectomy, C = chemotherapy, R = Radiotherapy, FH = Favorable histology WT, UFH = Unfavorable histology WT, $\mathrm{FU}=$ Follow up period, Hem. = hematuria

WT has the potential for both local and distant spread. Hematogenous metastases occur in lung, liver, bone, brain, or lymph nodes outside the abdomen, for which lungs are the most common sites of metastases. Direct invasion of WT into the collecting system rarely occurs, and therefore local recurrence and metastasis in urethra is very unusual. This does, however, predispose the patient to the distal urothelial spread of the tumor ${ }^{[30]}$. Urothelial spread is thought to be caused by exfoliation of the tumor cells and implantation along the path of the urine flow ${ }^{[30]}$ and as a result commonly reported sites of metastasis include the ureter and the ipsilateral ureterovesical junction, but not the urethra. Urethral metastasis has been described in only 2 previous cases ${ }^{[1,16]}$ (see Table 1 ). The first case report of urothelial implantation of WT was presented by Woodhead et al. in 1967 in a child with previous nephrectomy for WT ${ }^{[1]}$. The second case report appeared in the literature in 1998 by Lowe et al. ${ }^{[16]}$. We have presented a third case of urethral metastasis within this case report. In contrast to the two previously reported cases who presented with hematuria; our patient presented with a painful abdominal mass, both initially and on the urethral recurrence. In our case, the patient had a favorable histology, was blastemal-predominant, and presented with urethral recurrence within a 10-month period after nephrectomy and post-surgical radio and chemotherapy. Additionally, the recurrent tumor showed histologic features similar to the original tumor. This is in contrast to the case presented by Lowe et al. ${ }^{[16]}$ who had bilateral WT treated by chemotherapy and left nephrectomy at 6 months of age, followed by right nephrectomy at 6 years of age ${ }^{[16]}$. Lung and urethral metastases were discovered 6 months after the second nephrectomy in this patient. Our case also represents the only documented surviving case, with no evidence of disease recurrence during the 10 months follow up after presenting with the urethral recurrence. Unfortunately a short disease-free interval after initial treatment and metastasis to sites other than the lung usually indicate an aggressive tumor with poor outcome. Non-contiguous lower urinary tract involvement has been associated with poor prognosis, which is likely because these lesions often signify a recurrence of disease and more commonly occur in cases of widespread metastatic disease ${ }^{[5]}$. Ureteral and perhaps urethral extensions have also been reported to be more resistant to therapy ${ }^{[3,8,15]}$. The survival of our patient at 10 months follow up may be related to lead time bias resulting from more advanced diagnostic modalities and management strategies available today, compared to those available in $1968^{[1]}$ and 
$1998^{[16]}$. Whether the development of secondary urethral Wilms tumors in all three of these patients is attributed to the implantation of nephroblastoma cells on the distal urothelium or represents a true metastasis is not known. However, the urothelium was uninvolved in our case which argues against the former.

\section{References}

[1] Woodhead DM, Gigax JH, Wahle WH, et al. Urothelial implantation of Wilms’ tumors. Ann Surg. Jan 1968; $167(1)$ : 127-31. PMid: 4294819. http://dx.doi.org/10.1097/00000658-196801000-00021

[2] Taykurt A. Wilms tumor at lower end of the ureter extending to the bladder: case report. J Urol. 1972 Jan; 107(1): 142-3. PMid: 4333460.

[3] Chiba T, Ohashi E. Wilms tumor extending into the dilated renal pelvis as a mold. J Urol. 1980 Jul; 124(1): 130-1. PMid: 6251282.

[4] Johnson F, Luttenton C, Limbert D. Extrarenal and urothelial Wilms tumor Urology. 1980 Apr; 15(4): 370-3. http://dx.doi.org/10.1016/0090-4295(80)90472-0

[5] Stanley K, Khoudary KP, Nasrallah PF. Urothelial extension of Wilms tumor presenting as a prolapsing urethral mass. J Urol. 1995 Jun; 153(6): 1981-3. http://dx.doi.org/10.1016/S0022-5347(01)67384-1

[6] Ferris DO, Beare JB. Wilms' tumor; report of a case with unusual postoperative metastatis. Proc Staff Meet Mayo Clin. 1947 Mar 5; 22(5): 94-8. PMid: 20287353.

[7] Watkins JP. Wilms' tumor with ureteral metastases extending into the bladder. J Urol. 1957 Apr; 77(4): 593-6. PMid: 13417297.

[8] Pagano F, Pennelli N. Ureteral and vesical metastases in nephroblastoma. Br J Uroi. 1974 Aug; 46(4): 409-13. http://dx.doi.org/10.1111/j.1464-410X.1974.tb10178.x

[9] Stevens PS, Eckstein HB. Ureteral metastasis from Wilms tumor. J Urol. 1976 Apr; 115(4): 467-8. PMid: 177791.

[10] Mertz HO, Howell RD, Hendricks JW. The limitations of irradiation of solid renal tumors in children. J Urol. 1941; 46: 1103-1128.

[11] Mitchell CS, Yeo TA. Noninvasive botryoid extension of Wilms tumor into the bladder Pediatr Radiol. 1997; 27: 818-820. PMid: 9323251. http://dx.doi.org/10.1007/s002470050243

[12] Honda A, Shima M, Onoe S. Botryoid Wilms tumor: case report and review of literature.Pediatr Nephrol. 2000; 14: 59-61. PMid: 10654334. http://dx.doi.org/10.1007/s004670050015

[13] Fernandes ET, Parham DM, Ribeiro C, et al. Teratoid Wilms’ Tumor: The St Jude Experience. J Pediatr Surg. 1988; $23: 1131-4$. http://dx.doi.org/10.1016/S0022-3468(88)80328-2

[14] Groeneveld D, Robben SGF, Meradji M, et al. Intrapelvic Wilms tumor simulating xanthogranulomatous pyelonephritis. Pediatr Radiol. 1995; 25: S68-S69.

[15] Johnson F, Luttenton C, Limbert D. Extrarenal and urothelial Wilms tumor. Urology.1980; 15: 370-3. http://dx.doi.org/10.1016/0090-4295(80)90472-0

[16] Lowe LH, Banks WJ, Allen TD. Urethral metastasis in Wilms tumor. J Urol. 1998; 160(1): 165. http://dx.doi.org/10.1016/S0022-5347(01)63081-7

[17] Pastore G, Znaor A, Spreafico F, et al. Malignant renal tumours incidence and survival in European children (1978-1997): report from the Automated Childhood Cancer Information System project. Eur J Cancer. 2006; 42: 2103-14. PMid: 16919774. http://dx.doi.org/10.1016/j.ejca.2006.05.010

[18] Breslow N, Olshan A, Beckwith JB, et al. Epidemiology of Wilms tumor. Med Pediatr Oncol.1993; 21: 172-81. PMid: 7680412. http://dx.doi.org/10.1002/mpo.2950210305

[19] American Cancer Society. Cancer facts and figures 2015. Atlanta: American Cancer Society; 2015.

[20] Andrew MD. Wilms Tumor. Adv Pediatr. 2012; 59(1): 247-267. PMid: 22789581. http://dx.doi.org/10.1016/j.yapd.2012.04.001

[21] Jeffrey SD, Wilms Tumor Overview. GeneReviews ${ }^{\circledR}$ [Internet]. Pagon RA, Adam MP, Ardinger HH, et al., editors. Seattle (WA): University of Washington, Seattle; 1993-2014.

[22] Al-Hussain T, Ali A, Akhtar M. Wilms tumor: an update. Adv Anat Pathol. 2014 May; 21(3): 166-73. PMid: 24713986. http://dx.doi.org/10.1097/PAP.0000000000000017

[23] D’Angio JG, Breslow N, Beckwith BJ, et al. Treatment of Wilms' tumor: results of the Third National Wilms' Tumor Study. Cancer 1989.; 64: 349-60. http://dx.doi.org/10.1002/1097-0142(19890715)64:2<349::AID-CNCR2820640202>3.0.CO;2-Q

[24] Dome JS, Perlman EJ, Graf N. Risk stratification for wilms tumor: current approach and future directions. Am Soc Clin Oncol Educ Book. 2014: 215-23. PMid: 24857079. http://dx.doi.org/10.14694/EdBook_AM.2014.34.215

[25] Grundy P, Telzerow P, Moksness J, et al. Clinicopathologic correlates of loss of heterozygosity in Wilms' tumor: a preliminary analysis. Med Pediatr. Oncol. 1996; 27: 429-33.

http://dx.doi.org/10.1002/(SICI)1096-911X(199611)27:5<429::AID-MPO7>3.0.CO;2-O 
[26] Grundy PE, Telzerow PE, Breslow N, et al. Loss of heterozygosity for chromosomes 16q and 1p in Wilms' tumors predicts an adverse outcome. Cancer Res. 1994; 54: 2331-3. PMid: 8162576.

[27] Erginel B, Vural S, Akın M, et al. Wilms’ tumor: a 24-year retrospective study from a single center. Pediatr Hematol Oncol. 2014 Aug; 31(5): 409-14. PMid: 25007381. http://dx.doi.org/10.3109/08880018.2014.930767

[28] Yao W, Li K, Xiao X, et al. Outcomes of Wilms' tumor in eastern China: 10 years of experience at a single center. J Invest Surg. 2012; 25: 181-5. PMid: 22583015. http://dx.doi.org/10.3109/08941939.2011.615893

[29] So-Young Lee, Kyu-Rae Kim, Jung-Yeol Park, et al. Wilms’ Tumor with Long delayed Recurrence: 25 Years after Initial Treatment. Korean J Urol. Apr 2012; 53(4): 288-92. PMid: 22536475. http://dx.doi.org/10.4111/kju.2012.53.4.288

[30] Stevens PS, Eckstein HB. Ureteral metastasis from Wilms tumour. J Urol. 1976; 115: 467-8. PMid: 177791. 